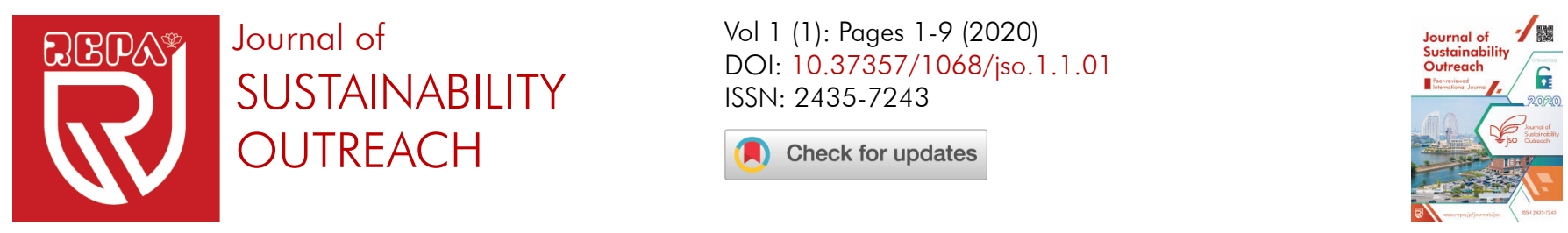

\title{
A study on sustainability of internal power generation compared with imported power in Af- ghanistan
}

Mohebullah Wali, Himayatullah Majidi, Milad Ahmad Abdullah and Mohammad Homayoun Yaqobi

Department of Electrical and Electronics Engineering, Faculty of Engineering, Kabul University, Kabul, Afghanistan

\section{Special Issue Articl \\ Open Access \\ Published}

Keywords

- Afghanistan power system

- Imported power

- Internal power generation

- Sustainability

- Energy resources

- Renewable energy

\section{ABSTRACT}

Currently, Afghanistan imports a high percentage of electric energy from the neighboring countries, while less attention has been paid on the utilization of internal domestic energy resources. Recently progress has been made with solar and wind energy, but other sources such as hydro energy remain underappreciated. Originally intended as a short-term solution to fulfill demand, the policy for importing power from neighboring countries is still in effect as energy demand has increased dramatically and exposed vulnerabilities in the existing power system. These issues can be categorized based on different aspects like technical, economic, political, security-related issues, natural disasters and many others that negatively affect the reliability of the energy sector. In this paper, the sustainability of the power system of Afghanistan is analyzed from different aspects. These multi-disciplinary problems are analyzed separately and linked with the weaknesses of the existing power system. The main objective of this study is to propose long-term solutions to the power sector by encouraging investment in the internal power generation to enhance sustainability and reliability. The proposed long-term solution also takes additional measures towards achieving sustainable development goals (SDG) such as economic growth, agricultural development, groundwater recharge, industrial development, flood and water control, job creation, and a green and clean environment.

Received: January 16, 2020; Revised: March 11, 2020; Accepted: March 20, 2020; Published: June 01, 2020

(C) 2020 REPA. All rights reserved.

\section{Introduction}

Afghanistan, whose total population to be about 32.53 million and the Gross Domestic Product (GDP) to be $\$ 20.04$ billion [1], is among the countries with the lowest percentage of the population who have access to electricity worldwide [2]. Even with significant domestic energy resources, only $30-38 \%$ of households have access to electricity. More than $75 \%$ of the population lives in rural areas, from which only $10 \%$ have access to electricity [3,4]. First implemented 15 years ago, a policy of importing electric power was intended to be a short-term solution. About $80 \%$ of the existing electric energy is imported from the neighboring countries, i.e., Tajikistan, Uzbekistan, Turkmenistan and Iran [5]. In 2011, the amount of imported electric energy from the four neighboring countries was $2.250 \mathrm{GWh}$, which makes up $73 \%$ of overall electric energy distribution within the country [6]. In 2012, the electricity consumption in Afghanistan was 364.665 GWh, from which $79.2 \%$ was imported from neighboring countries and $20.8 \%$ was domestically generated $(20.2 \%$ hydro and $0.7 \%$ thermal) [7]. In 2013, Afghanistan had a GDP of $\$ 687$ per capita, and energy consumption of 7.6 $\mathrm{kWh}$ per capita ranks among the lowest in the world [8].

Energy consumption rapidly increased from a load demand of 1,289,246 MWh in 2006 to 3,086,113 MWh in 2011 [6,7]. In 2014 the peak demand was $750 \mathrm{MW}$, and the unsuppressed electrical demand was estimated to be 2,500 MW [9]. The Afghanistan Power Sector Master Plan predicts the unsuppressed electric peak demand will reach around 3,500 MW in 2032 [10]. Consequently, seasonal outages are highly likely when power demand is very high given the insufficient energy supply available.

Despite having enormous available domestic energy capabilities such as hydro, solar, wind, bio and geothermal, little attention has been paid on their utilization. Figure 1 and Table 1 show the contribution and capacities available for domestic power generation. Afghanistan has around $581 \mathrm{MW}$ of domestic power capacity, of which 300 MW is hydropower (including micro-hydropower) and contributes about 52\%. $200 \mathrm{MW}$ from thermal (gas and oil) contributes around $34 \%$. Nearly $65 \mathrm{MW}$ is generated by distributed diesel generators and contributes $11 \%$. About $16 \mathrm{MW}$ comes from solar power and contributes $3 \%$. The largest generators of solar power include the 10 MW plant newly installed in Kandahar province and the 1.05-MW plant in Bamyan province. In contrast, 3.767 GWh were imported from neighboring countries in 20152016, estimated as $80 \%$ of the total grid supply [1]. Uzbekistan supplied the main amount of energy $(1,284 \mathrm{GWh})$ followed by Turkmenistan (1,184 GWh). Islamic Republic of Iran (827 GWh) and Tajikistan (471 GWh).

These data show the need for Afghanistan to develop a new energy strategy. Relying on imported power is not a sustainable solution and will be discussed in the upcoming sections. Instead, diversifying domestic energy resources, especially hydro due to its multi-sector benefits, is imperative in developing a long-term solution. 


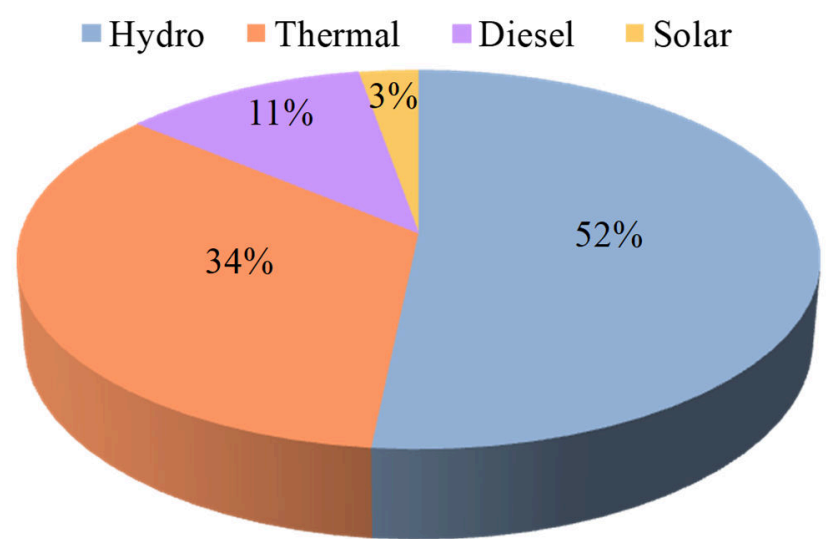

Figure 1. Afghanistan's installed internal generations and imported power capacities.

Table 1: Afghanistan's internal power generation capacities.

\begin{tabular}{ll}
\hline Resource type & Capacity (MW) \\
\hline Hydro & 300 \\
Thermal (Fuel Diesel/HFO) & 200 \\
Diesel Generator (Gen. Set.) & 65 \\
Solar & 16 \\
Total Capacity (MW) & 581 \\
\hline
\end{tabular}

The main objective of this paper is to outline the main problems with imported power, review the available internal energy resources, and discuss its advantages. Both power provision plans are evaluated from a sustainability, reliability and affordability point of view, and a long-term solution is proposed for satisfying future energy demand.

\section{Problems of imported power in Afghanistan}

Afghanistan's power system relies greatly on the imported power from neighboring countries. For many years, imported power has benefitted from nearly all investments and development in the energy grid, and little attention has been paid on developing and improving domestic power generation. This analysis focuses on the policy of imported power as a permanent solution and its shortterm and long-term consequences.

1- Building new power plants is a time-consuming process. Until a sufficient number of new plants is built that can close the gap of energy demand, the energy sector should import electricity from neighboring countries as a short-term solution. However, political instability of the region and the national government makes it challenging to be fully committed to building new power plants where there is need [10]. Because many contracts are dependent on both price and season, extension of those contracts cannot always guarantee that costs can be controlled and maintained within budget.

2- Dependency on imported power should be highly considered. Since imported power cannot be managed and controlled by the destination party, neighboring countries must address their own energy needs and often deliver electricity that reflects their own season-based needs. According to the Power Sector Master Plan of 2013, many agreements are seasonally-based; between 2015 and 2032, Tajikistan Sangtuda HPP only supplies power during summer. The lack of a supplementary source of electricity during the winter months when load demand increases for heating could result in inconvenient outages. Consequently, citizens are always subject to threats of insufficient power, especially during the peak load season.

3- Political instability throughout the region and the long period of war in Afghanistan further complicates relationships between the government and contracted parties, and the imported power supply may be threatened.

4- Lack of security and vulnerability to attacks on power transmission towers also cause frequent power outages. Repairing damaged towers and lines usually takes several days or weeks, but the delay could be longer in war zones. According to the Energy Infrastructure Attack Database (EIAD), about 500 attacks were recorded on energy infrastructure in 2011, and Afghanistan was listed among the four countries with the highest concentration of energy infrastructure attacks $[11,12]$. Furthermore, longer transmission lines are needed to access imported power within Afghanistan, and their security is not always guaranteed.

5- There are some technical issues related to the imported power that are outlined below:

- Technical issues might occur during power generation at the originating countries that could affect the amount exported to Afghanistan. How well these issues are addressed is not controllable by Afghanistan and would contribute to problems in the energy sector.

- With the exception of Turkmenistan, the power systems of the supplying neighboring countries are not synchronized with Afghanistan's energy grid. As a result, different sections of the energy grid operate at different voltages and currents. This lack of system standardization limits the ability for the network to expand and remain secure [1].

6- Economic concerns that should be taken into account include:

- According to the Power Sector Master Plan 2013 [10], negotiated cost rates differ between projects. The range of rates for imported power is between 2.0 cent/kWh from Turkmenistan to 8.5 cent/kWh from Uzbekistan [1,13]. A single rate for energy costs should be uniform throughout the country and should not differ from province to province.

- According to ADB 2015, imported energy costs have increased 14 times between 2007 till 2015 from \$16 million to $\$ 224$ million [14]. It is common practice for the Afghanistan government to subsidize part of the costs passed to consumers in need, but these 
increases threaten to bankrupt the national treasury even as the country is paying other nations as energy suppliers. The reports still show that from 2009 beyond, Afghanistan is mainly relying on the imported power and continually extends contracts. The corresponding graph in Figure 2 shows the investment amounts for imported power which increased from $\$ 55$ million in 2009 to $\$ 267$ million in 2016 , up by $385 \%$ during this period $[13,15]$. This shows how energy costs consume a larger and growing proportion of the nation's budget annually.

In conclusion, these multi-disciplinary issues show that while importing electricity was suitable as a short-term solution, it is not a sustainable and reliable way to meet the rising electric energy demand of Afghanistan. A stable and sustainable long-term alternative is needed to meet Afghanistan's energy demand and overcome the aforementioned disadvantages. To date, improvements to the energy grid have focused on the development of transmission lines used for delivering the imported power from the originating countries to south Asia in the future. Little progress has been made with developing domestic power generation. To overcome energy dependency, Afghanistan with its vast available internal resources should let its policy of power importation expire and set aside a set percentage of investments for domestic energy generation. As shown in the upcoming sections, the only way to overcome these issues is to support domestic power generation using internal energy resources.

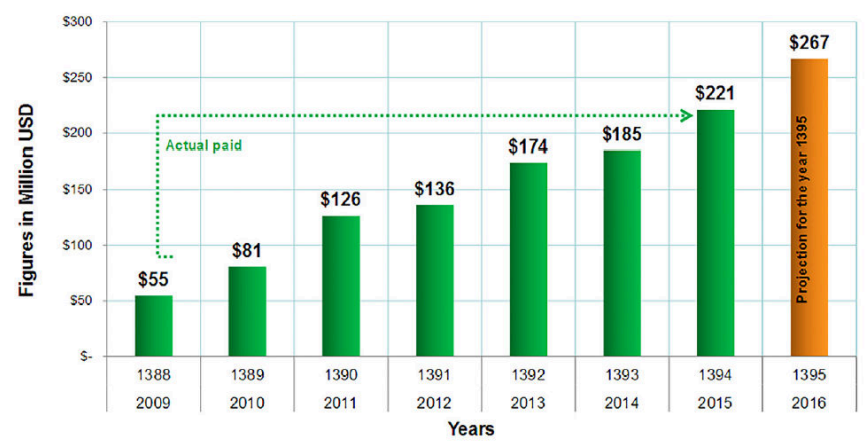

Figure 2. The cost of imported energy per year in Afghanistan [15].

\section{Overview of internal energy resources in Afghani- stan}

Afghanistan is one of the richest countries from the viewpoint of existing domestic energy resources. Several sources of renewable (hydro, solar, wind, biomass, biogas, geothermal) and non-renewable energy (oil, natural gas, coal, uranium) are available around the country. Despite the abundance of all these domestic resources, Afghanistan imports around $80 \%$ of its required electric energy from neighboring countries. Accessing renewable and non-renewable energies could make Afghanistan energy self-sufficient and potentially an energy exporter in the long-run [16]. Afghanistan's renewable energy capacities are shown in Figure 3 by-type. Estimates show that Afghanistan has the potential of about $222,000 \mathrm{MW}$ of solar, $67,000 \mathrm{MW}$ of wind, more than 23,000 MW of hydropower, 4,000 MW of biomass, and 3,500 MW of geothermal potential. However, only $10 \%$ of overall energy demand is provided from renewable energies, mainly hydropower [9].

\subsection{Solar Potential}

With an average of 300 sunny days per year, Afghanistan has an enormous solar energy potential [17]. The analysis of USA National Renewable Energy Laboratory (NREL) shows the central, eastern, and southern areas can produce large amounts of solar energy with average solar irradiance of $6.5 \mathrm{kWh} / \mathrm{m}^{2} /$ day on a horizontal plane [18]. The summer production capacity in high solar zones rises to $9.0 \mathrm{kWh} / \mathrm{m}^{2} /$ day. Many of these zones are close to the highly populated areas, which makes the produced electricity easily accessible to consumers [19]. Another study estimated the annual generation of solar energy potential in Afghanistan to be $146,982 \mathrm{GWh}$, consisting of 140,982 from solar photovoltaic and 6,000 GWh from concentrating solar power technologies [9]. The main installed solar photovoltaic hybrid plants all around the country include $100 \mathrm{~kW}$ in Syed Karam, $244 \mathrm{~kW}$ in Chal PV, and $400 \mathrm{~kW}$ solar-diesel hybrid and 1.05 MW Solar-diesel generator hybrid plants in Bamyan, and 2 MW solar-wind hybrid power plant in Herat province [20]. A solar plant newly constructed in Kandahar province has a capacity of 10 MW. These implemented projects tap into just a small part of the country's solar potential despite the vast need of energy in rural areas.

\subsection{Wind Potential}

According to the research conducted by NREL, there are significant wind potential regions in Afghanistan, especially during the winter [18]. The wind potential capacity is estimated to be around 67,000 MW which includes $36,000 \mathrm{~km}^{2}$ windy terrestrial area and on average 5 $\mathrm{MW} / \mathrm{km}^{2}$ generation capacity [17]. Shown in Figure 4 the wind zones are categorized into seven regions, i.e., (poor, marginal, fair, good, excellent, outstanding and superb). The fields with superb wind potential are located in Herat, Farah, and Nimroz provinces with wind speed over 8.5 $\mathrm{m} / \mathrm{s}$. The capacity factors (CF) for most of these fields are much higher (over 42) than the rest of the world (ranging between 20 - 35) [21]. Annual energy production (AEP) for the "superb" wind fields is estimated between 2,418 and 3,709 MWh/MW while the typical world AEP ranges between 1,752 and 3,066 MWh/MW.

Only two wind plants are in operation in Afghanistan. The first one was built in Punjsher province in 2008 with a capacity of $100 \mathrm{~kW}$ (wind-diesel hybrid project), in which the wind portion consists of 10 turbines each with a capacity of $10 \mathrm{~kW}$. The second plant is a solar-wind 
hybrid project installed in Herat province in 2017, of which 1.7 MW is solar photovoltaic and $300 \mathrm{~kW}$ is wind having three turbines each with a capacity of $100 \mathrm{~kW}$ [20].

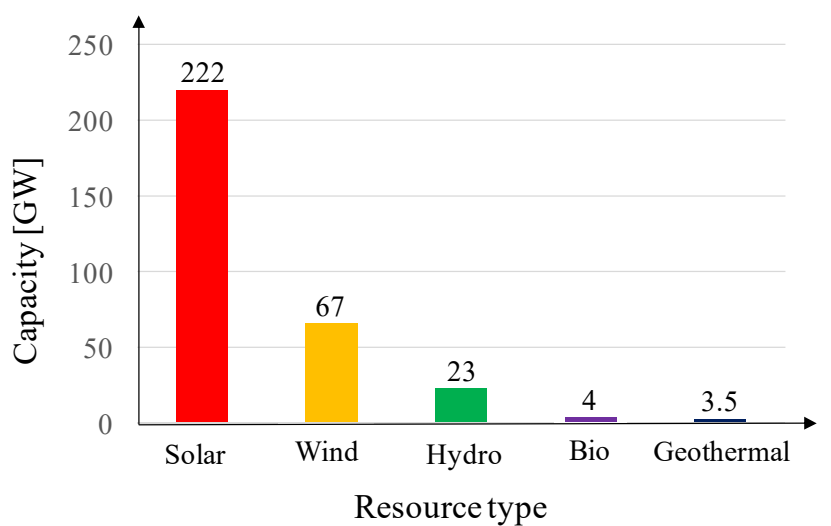

Figure 3. Capacities of available energy resources in Afghanistan.

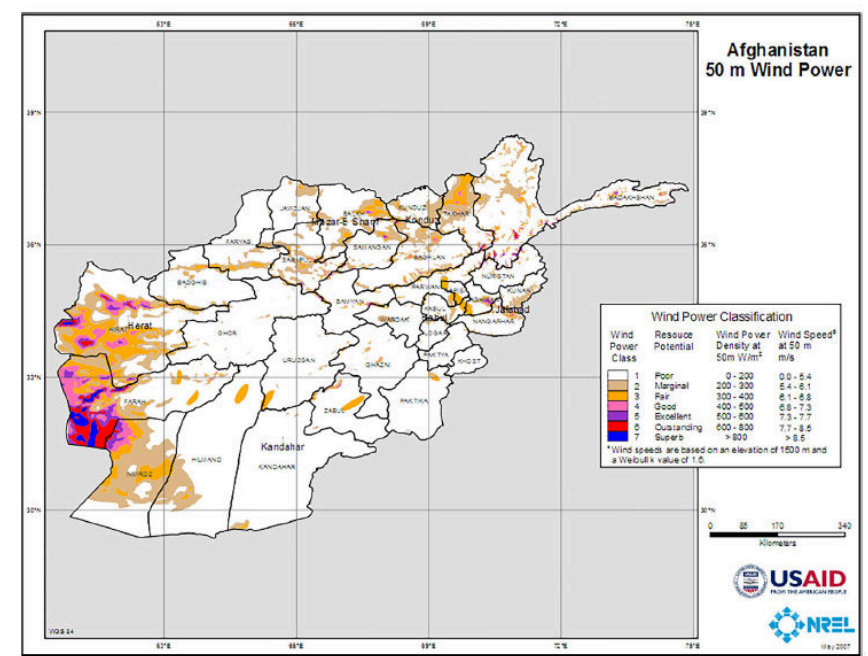

Figure 4. Wind potential regions' map in Afghanistan [18].

\subsection{Hydropower Potential}

As a mountainous country, Afghanistan has a great opportunity to provide hydro-energy along its main river systems. As depicted in Figure 5 four main river zones (Kabul, Panj Amu, Hilmand, and Harirod) are the main domestic sources of water from mountain snow and rainfall. A fifth northern-river system flows through Jawzjan and Balkh provinces. A preliminary technical survey estimated hydropower potential in Afghanistan to be more than 23,000 MW [22]. Table 2 summarizes hydropower potential in Afghanistan for each zone and relevant tributary rivers. Nearly $87 \%$ of hydropower production capacity $(20,000$ MW) is available on north-east on the Panj-Amu river and its other tributary rivers (Panj and Kokcha) flowing along the borders of Afghanistan, Tajikistan, and Uzbekistan. In addition, the Kunar river basin offers opportunities for hydropower. Based on a preliminary survey and shown in Table 3 there are six possible sites for the construction of hydropower dams on this river [20]. The total capacity of these hydropower sites is about 2,800 MW.
Table 2: Hydro potential resources in Afghanistan by zone [23].

\begin{tabular}{llll}
\hline \hline No. & Zone & River & Potential (MW) \\
\hline 1 & Kabul & Kabul & 408 \\
2 & & Panjsher & 400 \\
3 & & Laghman & 44 \\
4 & & Kunar & 1,089 \\
5 & Panj Amu & Panj & 9,050 \\
6 & & Amu & 9,110 \\
7 & & Kokcha & 1,927 \\
8 & & Kunduz & 50 \\
9 & Northern & Jawzjan & 460 \\
10 & \multirow{4}{*}{ Harirod-Murghab } & Harirod & 300 \\
11 & Murghab & 102 \\
12 & \multirow{2}{*}{ Hilmad } & Hilman & 100 \\
13 & Farah Rud & 80 \\
14 & \multirow{2}{*}{ Total Capacity (MW) } & 23,310 \\
\hline
\end{tabular}

Table 3: Available hydropower potential on Kunar River ba$\sin [20]$.

\begin{tabular}{ll}
\hline \hline Site name & Estimated power generation (MW) \\
\hline Shal & $798 \mathrm{MW}(7$ Units $\times 114 \mathrm{MW})$ \\
Sagi & $300 \mathrm{MW}(5$ Units x 60 MW) \\
Chunek & $390 \mathrm{MW}(4$ Units $\times 97.5 \mathrm{MW})$ \\
Dab & $450 \mathrm{MW}(4$ Units $\times 112.5 \mathrm{MW})$ \\
Lar Sultan & $390 \mathrm{MW}(3$ Units $\times 130 \mathrm{MW})$ \\
Surtaq & $410 \mathrm{MW}(4$ Units $\times 102.5 \mathrm{MW})$ \\
Total Capacity $(\mathrm{MW})$ & 2,738 \\
\hline
\end{tabular}

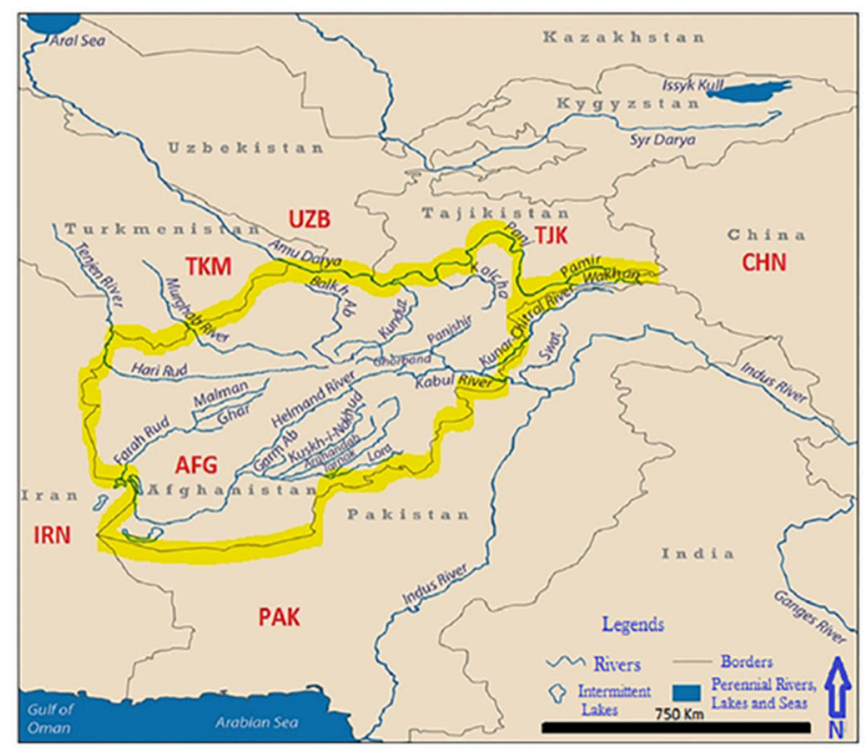

Figure 5. Afghanistan rivers excluding the expression of territory, boundary and legal status of included countries [24].

At present, 125 sites have been identified for micro-hydropower (MHP) projects that can generate more than 600 MW each for rural electrification [25]. The Ministry of Energy and Water (MEW) and Ministry of Rural Rehabilitation and Development (MRRD) estimate the total installed capacity of MHP plants (MHPs) across the country 
is 36.907 MW. Additional MHP's with a total capacity of 5.845 MW are under construction, as are other plants jointly built under MEW and MRRD with capacity of 10.144 MW.

The master plan for the Afghanistan power sector (from 2013 to 2032) identifies four stages of power sector development [10]. Stage A focuses on imported power until 2015. Stage B focuses on the internal grid improvements until 2020. Stages C and D refers to long-term expansion projects planned to be implemented in 2025 and 2032 respectively, and mainly focus on domestic power production especially hydropower. The total investments required for stage-A and B are estimated to be $\$ 1,213$ and $\$ 1,465$ million, while stage $C$ and stage $D$ are estimated at $\$ 1,410$ and $\$ 6,010$ million, respectively. The goal is to increase the percentage of domestic energy generation (from $45 \%$ to $67 \%$ ) and residential access to electricity (70 to $83 \%$ ) by 2032 .

Though we have calculated domestic hydro energy potential as 23,000 MW, the Afghanistan Energy Sector Master plan estimates a total of $253.71 \mathrm{MW}$ of hydropower generated domestically by 12 hydropower plants planned to be operational by 2015 . This estimated total installed hydropower capacity plus 36.907 MW of installed MHPs show a very limited use of domestic hydroelectric capacity.

- Biomass Potential: In 2014, the Afghanistan Renewable Energy Policy (AREP) estimated biomass potential throughout the country to be $4,000 \mathrm{MW}$ including 3,090 MW from agricultural waste, 840 MW from animal waste, and $91 \mathrm{MW}$ from municipal solid waste [26]. Heating and cooking energy needs are traditionally met with wood and dung $[27,28]$. The primary sources of biomass potential are crop residues, firewood, animal manure, and municipal waste. According to Afghanistan Living Conditions Survey (ALCS), $74 \%$ of all households and $90 \%$ of rural households relied on biomass as their primary fuel for cooking while $82 \%$ of all households and $90 \%$ of rural households use biomass as their primary source of heat [29]. Nearly 39.2 MT of animal waste is produced annually, capable of generating 1,567 million $\mathrm{m}^{3}$ of biogas (7,367 GWh of energy). In addition, about 3.72 MT of municipal solid waste produced annually can generate 819 GWh. Moreover, about 6.5 MT of crop residue produced annually can generate $27,083 \mathrm{GWh}$ $[27,28]$. In rural areas, wood and charcoal are mainly used for heating and cooking purposes, but biogas produced from animal waste can also be a good energy source [30]. According to NREL estimations, around 896,000 small biogas energy plants using cattle manure can be built in Afghanistan. These plants can supply $26 \%$ of the population with clean energy. There are 500 digesters installed in rural areas in Afghanistan that generate biogas from animal manure and municipal solid waste [31]. About 300 units of these digesters are installed in the south mainly by MRRD; nearly 100 units are installed by Agency for Rehabilitation and Energy Conservation (AREA) and Bremen Overseas Research and Development Association (BORDA) producing an annual average energy of 1,896 to $2,654 \mathrm{MWh}$.

- Geothermal Potential: Geothermal energy sources in Afghanistan supply underground high-temperature water or steam that can be used for the production of electricity [31]. Active geothermal systems are found in the Hindu Kush which runs along the Herat fault system up to the Wakhan corridor in the Afghan Pamir $[26,32]$. Geothermal energy potential is estimated to be 3,500 MW [27]. About 70 geothermal sites have been identified where individual power plants with capacities from 5 to $20 \mathrm{MW}$ can be built. Each geothermal power plant requires on average a total of $400 \mathrm{~m}^{2}$ of land per gigawatt of generated electric power for a period over 30 years, a smaller footprint compared to the huge acreages needed for other power plants [32]. There is no geothermal power plants currently in operation.

\section{Multi-sector developments through internal power generations}

Afghanistan struggles to provide electricity to its population in improving reliability and expanding its electrical grid to connect with remote rural areas. Sustainable solutions require disinvestment in imported electricity and increased commitment in domestic energy sources whose potential has not been fully realized and could be used to address anticipated electricity demand in 2032. Developing internal sustainable energy sources positions Afghanistan as an energy exporter and stimulates domestic economic growth. The feasibility of transitioning to sustainable domestic internal energy generation, especially biomass and geothermal, needs to be analyzed. Here are some benefits that such a transition is expected to provide:

\subsection{Sustainable and reliable electrification}

Developing internal power plants that rely on sustainable, renewable energy sources should overcome the nation's dependency on purchasing electricity from other nations. Proper network and infrastructure design can significantly improve the feasibility of making this transition towards accepting domestic energy as a sustainable and reliable source.

\subsection{Economic growth}

Developing domestic sources of sustainable energy will save millions of US dollars currently sent to neighboring countries to purchase energy (Figure 2). The savings can be reinvested in maintenance and expansion of domestic power plants and the electrical delivery grid, stimulating 
economic growth. Furthermore, revenue from selling energy to neighboring countries will contribute to the economy.

\subsection{Agricultural development}

Afghanistan's economy is mainly based on agriculture and farming, contributing around 50\% of GDP and involving almost $80 \%$ of the population [33]. The country is landlocked with a total area of $652,000 \mathrm{~km}^{2}$, of which $82 \%$ is barren; less than $2 \%$ is forest, and about $10 \%$ of the territory is arable. One-quarter of the country lies 2,500 meters above the sea level; rainfall and snow replenish the country's water reservoirs. In the year 2011, renewable water capacity was estimated to be 65 billion $\mathrm{m}^{3}$ per year [34], of which a vast amount flows to the neighboring countries without utilization. Additional freshwater demands are satisfied by tapping groundwater for drinking and irrigation and water from river basins in neighboring nations. In 2000, the total water withdrawal was estimated to be 20 billion $\mathrm{m}^{3}$ per year, for which $98 \%$ was used for agricultural purposes. Diesel water pumps are used to take water from the ground for irrigation, but it comes at a cost that weakens domestic agricultural production. To overcome these problems, development of internal hydropower dams is suggested as a solution by forming reservoirs and control water usage through proper management systems. In addition, hydropower dams can also increase the amount of arable land in the country.

\subsection{Water and flood control}

The spring and fall seasons bring floods throughout the country, resulting in a loss of life and damage to property, livestock, arable land, and forests. Proper flood and water management through a system of dams and irrigation canals can mitigate this damage, help control excess flood water, and produce hydropower.

\subsection{Groundwater recharge and provision of potable water}

During the summer and fall seasons, underground water discharge increases. Hydropower dams create reservoirs that allow replenishment of ground water. Access to clean potable water also remains a challenge to many residents due to agricultural activities, population growth, quality of sanitation, storage of water in the dry season, and the network of canals [33]. Over the last four decades, urban development authorities have not adequately considered these challenges. The ground water near urban areas is highly polluted due to high population density and inadequate management of waste and industrial water discharge. Construction of groundwater sanitation and treatment plants are becoming more prohibitive water needs more running costs. Diverting some water used for hydropower after treatment as potable water can reduce its cost to residents, justifying installation of MHP turbines in water treatment plants, as suggested in a feasibility study report of Dahla dam hydropower development in Kandahar province, conducted by the ADB in 2019 [35]. Specifically, the report shows the feasibility of building two hydropower stations. The larger power station can provide water required for irrigation and for protecting the downstream aquatic environment. The other MHP station can be installed to deliver water required for municipal and industrial needs including potable water.

\subsection{Job Creation and Poverty Reduction}

Most of Afghanistan's population lives in rural areas. Surveys indicate that $55 \%$ of the total population lives in poverty, and the overall unemployment rate is $24 \%$ [36]. $80 \%$ of the nation's population work in agriculture and service professions. As the cost of working in agriculture increases, the number of citizens in poverty increases as well. In addition, many factories and industries have closed due to the lack of electricity $[37,38]$, which has contributed to joblessness and poverty. Thousands of students who have earned undergraduate or graduate degrees find themselves unemployed. Investing in developing domestic energy sources is expected to have a positive effect. Sustainable and affordable domestic energy production should revive shuttered factories and encourage investment and influence economic productivity by opening new employment opportunities and reducing levels of poverty. By providing electricity to rural areas, Afghanistan can raise its standard of living and quality of education.

\subsection{Making environment green}

According to ALCS, $74 \%$ of all households and $90 \%$ of rural households in Afghanistan use biomass as their main fuel for cooking. Similarly, $82 \%$ of all households and $90 \%$ of rural households utilize biomass as their primary source of heat. Available biomass sources include coal, wood, and crop waste. However, during the winter season, inefficient consumption pollutes the air and releases a high concentrations of harmful greenhouse gases such as $\mathrm{CO}_{2}, \mathrm{CO}, \mathrm{PM} 2.5$ and PM10 that cause disease. The problem of air pollution is mainly caused by the lack of reliable electricity, lack of service to rural households and the rising costs to the consumer. These challenges can be solved by providing sustainable and affordable energy supply through domestic power generation. Developing biogas and biomass energy plants can help with efficient processes for capturing and processing municipal waste especially in urban areas. Finally, construction of hydropower dams will improve efforts to control and mitigate climate change.

\section{Research Methodology}

Figure 6 shows the four steps that define this research. In Steps 1 and 2, the current scenario of Afghanistan's power sector and the available renewable energy resources were respectively reviewed through data collection from literature and official reports. The validity and accuracy of collected data were confirmed through interviews conducted with the technical staff of MEW, Da Afghanistan Breshna 
Sherkat (DABS) and MRRD. In Step 3, we looked at how future projects and the Master Plan addressed sustainability in addressing the central problems of importing power and connecting to the existing grid and weighing the advantages and challenges of developing domestic energy power sources. Finally in Step 4, the sustainability of the cases (expanding imported power versus development of domestic power generation) were compared. A stable, sustainable and long-term solution was proposed for multi-sector development and for moving towards attaining Sustainable Development Goals (SDG). Recommendations were also proposed to address existing obstacles to develop domestic power.

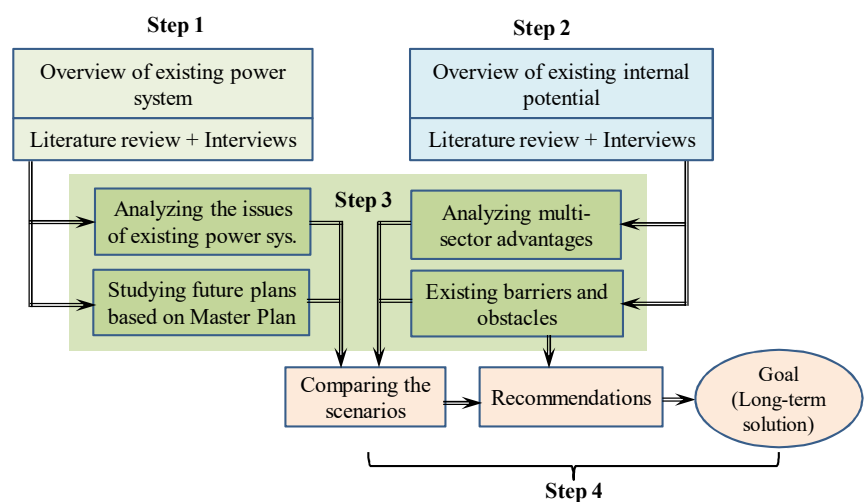

Figure 6. Flow chart of research methodology.

\section{Long-term solutions, barriers, and recommenda- tions}

Considering the problems related to the imported power and the advantages behind extension of domestic power systems, it is realized that reserving a percentage to invest in developing domestic power sources will not only provide sustainable, stable and self-sufficient energy supply but also stimulate multi-sector developments. As a result, Afghanistan will take steps towards achieving Sustainable Development Goals (SDG). Because building hydropower plants has multi-sector advantages and provides a more productive environment, the authors recommend that the development of centralized, on-grid hydropower plants should be a top priority. For rural areas, solar, wind, geothermal, biomass and MHP plants are more suitable as offgrid distributed power systems for rural electrification and developments.

Many challenges and barriers oppose developing renewable energy and are widely discussed in the literature $[9,31,33,39,40]$ : political instability, weakened government, low economic level, insecurity, weak regulations, lack of cooperation among key players, corruption, dispute of water rights between neighboring countries, high investment costs of renewable energy development, lack of workforce expertise, and lack of private sector participation. To overcome these challenges, we make the following suggestions to the government and energy sector stakeholders:

1- Share ideas and centralize decision-making and planning processes to improve coordination as the "Power Sector Union (PSU).” Develop technical relationships with key stakeholders such as universities, research centers and the main organizations/ministries playing the key roles in the power sector.

2- Review and revise current policies, laws, and regulations in order to strengthen coordination among the key stakeholders and PSU during planning and implementation of renewable energy projects.

3- Support the universities and vocational institutes by developing and revising training curricula based on assessments of the needs of the power sector. Build laboratories and practical experiences that encourage project design and evaluation through funding research grants and internship mechanisms.

4- PSU should analyze the above-mentioned obstacles and barriers against the implementation of internal power generations and develop appropriate suggestions and solutions.

5- PSU should classify, prioritize, and schedule Stage C and $\mathrm{D}$ projects in the master plan that were designated for Afghanistan's power sector improvements.

6- Strengthen relationships among the key players in the energy sector such as MEW and MRRD to prioritize and better coordinate implementation of feasible renewable energy projects across the country.

7- Increase investment efforts and funding projects with long-term impact to assist Afghanistan by funding those projects that tend to long-term solutions to the power sector.

8- Engaging private sector interest through revised policies and government incentives to accelerate domestic renewable energy development.

9- Focus hydropower development in central parts of Afghanistan to avoid conflicts with neighboring countries and reduce national dependency on imported power.

10- Initiate feasibility studies, land acquisitions, and resettlement processes to begin planning and constructing hydropower plants in central areas.

11- Categorize and prioritize projects based on economic impact, feasibility and sustainability, especially for distributed power generation projects such as solar, wind, biomass in rural areas.

12- To establish Afghanistan as a credible power exporter in the future, PSU should negotiate trans-boundary water-sharing agreements with neighboring countries under international rules and regulations. 
13- Develop a strategy to promote and improve efficient power consumption, i.e., reduce network power losses and raise consumer awareness towards energy efficiency through public education and using energysaving equipment.

14- Learn from other countries' experiences in addressing similar obstacles towards developing domestic renewable energy sources and consider adopting any best practices.

These recommendations focus on three main categories: power generation, efficient energy consumption, and adequate policies, but it is important to make sure that power providers and consumers are also satisfied with the transition to sustainable domestic energy supply.

\section{Conclusion}

By providing stable, sustainable, self-sufficient energy, developing domestic energy results in long-term multi-sector benefits such as economic growth, increased agricultural productivity, groundwater recharge, industrial growth, flood and water control, job creation, and a green and clean environment. Unlike with imported power, the multi-sector improvements from internal power generation is sustainable. Even with the barriers to developing domestic power, a country with such an enormous supply of available renewable energy should not rely on imported energy. It is essential for the Afghan government to focus on taking advantage of these assets and overcome the challenges and barriers in transitioning. The opportunity is available to make the country independent of energy imports, satisfy the domestic energy demand, and improve the quality of life for all. Every single renewable resource should help meet the unsuppressed demand estimated for 2032. Further work is required to improve the strategic plans, regulations, laws, and policies to study, analyze, classify, prioritize, estimate, design and implement renewable energy projects. Finally, it should be a top priority to develop hydropower because of its multi-sector benefits.

\section{References}

[1] Afghanistan renewable energy development issues and options (2018) Washington, D.C. 107 p.

[2] World Bank (2013) "Toward a sustainable energy future for all: Directions for the World Bank Group's energy sector" Washington, D.C. 31 p.

[3] Alamyar KM (2014) "Renewable energy for sustainable development” Kabul. 1-14 p.

[4] Afghanistan rural renewable energy policy (2013) Kabul. $20 \mathrm{p}$.

[5] Danish MSS, Senjyu T, Sabory NR, Danish SMS, Ludin GA, et al. (2017) "Afghanistan's aspirations for energy independence: Water resources and hydropower energy" Renewable Energy (vol. 113, pp. 1276-1287) https://doi.org/10.1016/j.renene.2017.06.090
[6] Neifer R (2014) “Technical assistance consultant's report Afghanistan: Addendum to the Afghanistan power sector master plan" Stuttgart. 127 p.

[7] Afghan Energy Information Center (AEIC) (2012) "Electricity monthly production report" Kabul, Afghanistan, Afghan Energy Information Center (AEIC). (http://aeic.af/)

[8] Power sector master plan. Technical assistance consultants report: Project number 43497 (2013) Kabul.

[9] Ahmadzai S, McKinna A (2018) "Afghanistan electrical energy and trans-boundary water systems analyses: Challenges and opportunities" Energy Reports (vol. 4, pp. 435469) https://doi.org/10.1016/j.egyr.2018.06.003

[10] Fichtner GmbH (2013) "Islamic Republic of Afghanistan: Power sector master plan" (pp. 451)

[11] Danish MSS, Sabory NR, Danish SMS, Senjyu T, Ludin GA, et al. (2017) "Electricity Sector Development Trends in an After-war Country: Afghanistan Aspiration for an Independent Energy Country" Journal of Energy and Power Engineering (vol. 11, no. 1, pp. 553-557) https://doi.org/10.17265/1934-8975/2017.08.007

[12] Sadiqi M. (2012) "Basic design and cost optimization of a hybrid power system in rural communities in Afghanistan. MSc Thises." The Kansas State University

[13] Safi, R. \& Sharma MP (2019) "Energy scenario of Afghanistan" IOSR Journal of Engineering (IOSRJEN) (vol. 9, no. 4, pp. 50-59)

[14] Energy supply improvement investment program, sector assessment summary: Energy (2015) Kabul.

[15] Da Afghanistan Breshna Sherkat (DABS) (2016) "CASA and TUTAP Power interconnection project" Islamabad. $16 \mathrm{p}$.

[16] Bochkarev D (2014) "Afghanistan reconnected: Linking energy supplies toconsumers in Asia" New York. 28 p.

[17] Ministry of Energy and Water (MEW) and Ministry of Rural Rehabilitation and Development (MRRD) (2013) "Afghanistan Rural Renewable Energy Policy" Kabul, Ministry of Energy and Water (MEW) and Ministry of Rural Rehabilitation and Development (MRRD).

[18] National Renewable Energy Laboratory (NREL) (2011) "Afghanistan-NREL Resource Maps and Toolkits" National Renewable Energy Laboratory (NREL). (https://www.osti. gov/biblio/982282-solar-wind-resource-assessments-afghanistan-pakistan) Accessed: 18 October 2019

[19] Burns RK (2011) “Afghanistan: Solar assets, electricity production, and rural energy factors" Renewable and Sustainable Energy Reviews (vol. 15, no. 4, pp. 2144-2148) https://doi.org/10.1016/j.rser.2010.12.002

[20] Regional projects and masterplanning - Overview (2019) Inter-ministerial Commission of Energy (ICE)

[21] Ershad AM (2017) "Institutional and policy assessment of renewable energy sector in Afghanistan" Journal of Renewable Energy (vol. 2017, pp. 1-10) https://doi.org/10.1155/2017/5723152

[22] Samadi AR (2011) "Energy consumption and available energy resources in Afghanistan" Kabul. 23 p.

[23] Renewable energy department database (2015) Ministry of Energy and Water (MEW) (https://nwara.gov.af/en) Accessed: 16 November 2019

[24] Ahmadzai S, McKinna A (2018) "Afghanistan electrical energy and trans-boundary water systems analyses: 
Challenges and opportunities" Energy Reports (vol. 4, pp. 435-469) https://doi.org/10.1016/j.egyr.2018.06.003

[25] Meisen, P., Azizy P (2008) "Rural Electrification in Afghanistan: How do we electrify the villages of Afghanistan?" San Diego. 26 p.

[26] Afghanistan renewable energy policy (2013) Kabul.

[27] Afghanistan energy sector update (2016) Kabul.

[28] Milbrandt A, Overend R (2011) "Assessment of biomass resources in Afghanistan" Colorado. 45 p.

[29] Afghanistan living conditions survey 2013-2014: National risk and vulnerability assessment (2019) Kabul.

[30] Fahimi A, Upham P (2018) "The renewable energy sector in Afghanistan: Policy and potential" Wiley Interdisciplinary Reviews: Energy and Environment (vol. 7, no. 2, pp. e280) https://doi.org/10.1002/wene.280

[31] Ludin GA, Matayoshi H, Danish MSS, Yona A, Senjyu T (2017) "Hybrid PV/Wind/Diesel Based Distributed Generation for an Off-Grid Rural Village in Afghanistan" Journal of Energy and Power Engineering (vol. 11, no. 2, ) https://doi.org/10.17265/1934-8975/2017.02.003

[32] Saba DS et al. (2004) "Geothermal energy in Afghanistan: prospects and potential" New York. 38 p.

[33] Habib H (2014) "Water related problems in Afghanistan"
International Journal of International Studies (vol. 01, no. 03, pp. 137-144) https://doi.org/10.29171/azu_acku_ pamphlet_td313_a3_h335_2014

[34] Palau RG (2013) "Water security: Afghanistan transboundary water resources in regional context" Transboundary Issues (vol. 5, no. 1, pp. 1-15)

[35] Asian Development Bank (ADB) (2019) "Technical assistance consultant's report - Feasibility study report component 3: Water supply" Kabul. 62 p.

[36] Mundi index (2019) Index Mundi (https://www.indexmundi.com/) Accessed: 16 November 2019

[37] Watson P (2011) “Kandahar struggles for reliable electricity" (https://www.thestar.com/news/world/2011/01/25/ka ndahar_struggles_for_reliable_electricity.html) Accessed: 16 November 2019

[38] Glasse J (2013) "Eastern Afghanistan struggles for power"

[39] Atef SS, Sadeqinazhad F, Farjaad F, Amatya DM (2019) "Water conflict management and cooperation between Afghanistan and Pakistan" Journal of Hydrology (vol. 570, pp. 875-892) https://doi.org/10.1016/j.jhydrol.2018.12.075

[40] Hanasz P (2012) "The politics of water security between Afghanistan and Iran" Published by Future Directions International Pty Ltd 